Plant Tissue Cult. \& Biotech. 31(1): 35-42, 2021 (June)

(CBangladesh Assoc. for Plant Tissue Culture \& Biotechnology

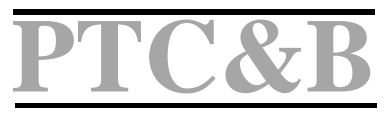

\title{
An Improved liquid Culture System for Efficient Shoot Multiplication in Aerva lanata (L.) Juss. Ex Schult.
}

\section{Kandhan Varutharaju ${ }^{1}$, Chandrasekaran Thilip ${ }^{2}$, Palusamy Raja, Ganesan Thiagu, Abubakker Aslam and Apakkan Shajahan*}

Plant Molecular Biology Laboratory, Department of Botany, Jamal Mohamed College, Tiruchirappalli - 620 020, Tamilnadu, India

Key words: Aerva lanata, Liquid medium, Plant growth regulators, Shoot multiplication

\begin{abstract}
An improved in vitro mass propagation protocol was developed for Aerva lanata using MS liquid medium. The influence of MS medium (solid and liquid) with cytokinin (TDZ and BAP, respectively) were studied for shoot proliferation and growth. The liquid medium perfomed better than solid medium in shoot multiplication. The maximum shoot multiplication rate was (29.37 \pm 0.64 shoots per explant), obtained in MS liquid medium which is containing $0.6 \mathrm{mg} / \mathrm{TDZ}, 0.3 \mathrm{mg} / \mathrm{NAA}$ and $0.2 \mathrm{mg} / \mathrm{IBA}$. Different volumes of liquid medium have been used, $30 \mathrm{ml}$ of medium flask showed the maximum number of shoots. Liquid medium is better suited for in vitro propagation of A. lanata since the enhanced multiplication rate was observed with shorter subculture intervals.
\end{abstract}

\section{Introduction}

Aerva lanata is an important medicinal plant belonging to the Amaranthaceae family. It is an erect, herbaceous weed plant, which grows everywhere in the plains of India. The whole plant, especially leaves are edible and used as food (Joseph and Mathew 2015). In the traditional system of medicine, A. lanata is used as diuretic, anti-helminthic, antidiabetic and expectorant (Gupta and Neeraj 2004). It is also extensively used for many purposes in the form of ailments like arresting haemorrhage during pregnancy, burn healing, anti-inflammatory, skin diseases, for uterus clearance after delivery and to prevent lactation (John 1984).

*Author for correspondence: <shajahan.jmc@gmail.com>. ${ }^{1}$ Department of Botany \& Biotechnology, Selvamm Arts and Science College (Autonomous), Namakkal-637 003, Tamilnadu, India. ${ }^{2}$ Department of Botany, Periyar University Constituent College of Arts and Science, Sendamangalam-637 404, Namakkal-Dt, Tamilnadu, India.

DOI: https://doi.org/10.3329/ptcb.v31i1.54109 
The plant extract is also used to treat nasal bleeding, cough, scorpion sting, fractures and spermatorrhoea (Mukerjee et al. 1984, Sikarwa and Kaushik 1993, Girach et al. 1994). The flowers are used for dysentery, diarrhoea and bronchitis. The seeds are find to use in rheumatism and bronchitis. The plant leaves are also used for antimalarial, in fever and to expel stones from kidney, scorpion sting, spermaorrhoea, urinary troubles and antirheumatic. Further, the root is used for headache, scabies, cough, as demulcent, diuretic, to cure diarrhea, jaundice, cholera, dysentery and snake bite (Rajesh et al. 2011).

A. lanata is reported to be very effective in curing urinary risk factors associated with calcium oxalate urolithiasis and no side effects (Selvam et al. 2001, Surya et al. 2012). The plant contains bioactive compounds are responsible for the above pharmacological activities such as $\beta$-carboline, $\beta$-sitosterol, palmitic acid, alphaamyrin, aervin, methyl aervine, and aervoside (Varutharaju et al. 2014). The liquid culture system for in vitro mass propagation helps in the substantial reduction of plantlet production costs (Sandal et al. 2001) and it is an important step towards automation (Aitken-Christie et al. 1995).

Further, liquid medium provides other advantages in the form of uniform culturing conditions, renewal of media without changing the container, sterilization by microfilteration and ease of cleaning containers. The liquid culture system is highly efficient for multiple shoot proliferation, cell suspension culture, adventitious root formation and adventitious shoot proliferation in various plantspecies (Sivanandhan et al. 2013, Soundar Raju et al. 2015, Thilip et al. 2015, Arigundam et al. 2020). However, several reports indicate that a liquid culture system promotes hyperhydricity (Deterz et al. 1994) and is limited by low oxygen content (Smith and Spomer 1995). Although there are a few reports for in vitro propagation of A. lanata (Varutharaju et al. 2014, Shekhawat et al. 2016), there has been no study conducted on the comprehensive assessment of the potential of a liquid culture system for its mass propagation of $A$. lanata. The present work focus on the study of various parameters associated with the development of an efficient liquid culture system for in vitro mass propagation of $A$. lanata.

\section{Materials and Methods}

Three months old in vitro raised healthy node and shoot bud segments of $A$. lanata were used in this experiment. To optimize the concentration of cytokinins for shoot induction and proliferation, the MS solid medium with different concentration of cytokinins TDZ (0.3, 0.6 and $0.9 \mathrm{mg} /)$ and $\operatorname{BAP}(0.3,0.6$ and $0.9 \mathrm{mg} \Lambda)$ was used. Both solid and liquid medium was adjusted to $\mathrm{pH} 5.6-5.8$ before autoclaving for $20 \mathrm{~min}$ at $121^{\circ} \mathrm{C}$. The cultures were incubated at $24 \pm 2^{\circ} \mathrm{C}$ under 16/8 (light and dark cycle) photoperiod ( $40 \mu \mathrm{mol} \mathrm{m}^{-2} \mathrm{~s}^{-1}$ ) and irradiance provided by cool-white fluorescent (Philips, India). Further, after 2 weeks shoot induction cultures were recorded.

To determine the shoot multiplication rates in both solid and liquid MS medium supplemented with concentration of $0.6 \mathrm{mg} / \mathrm{TDZ}$ and $0.6 \mathrm{mg} / \mathrm{BAP}$ in combination of 
$0.3 \mathrm{mg}$ /NAA, $0.2 \mathrm{mg}$ / IBA were observed. Different growth parameters such as shoot length, root length, number of shoots/explants, fresh weight and dry weight $\left(60^{\circ} \mathrm{C}\right)$ and clusters of plantlets were recorded after 4 weeks of culture.

To optimize the liquid medium conditions for growth and shoot proliferation of $A$. lanata. Different volumes of MS liquid medium (10, 20, 30, 40 and $50 \mathrm{ml}$ ) were supplemented with $0.6 \mathrm{mg} / \mathrm{TDZ}, 0.3 \mathrm{mg} / \mathrm{NAA}, 0.2 \mathrm{mg} / \mathrm{IBA}$ and sucrose (3.0\%) were tested in a conical flask. The mean number of shoots produced per explants was recorded at regular intervals of 14, 21, 28 and 35 days. After 14 days, various parameters like root induction period, root length and branching of roots were recorded.

All experiments were repeated thrice and each with three replicates. Data were recorded after 4 weeks of culture for multiple shoot formation in liquid culture. Data were statistically analyzed using of variance (ANOVA). Data were presented as mean \pm standard error (SE). The mean separations were carried out using Duncan's multiple range test using the SPSS and significance was determined at $p<0.05$ was performed.

\section{Results and Discussion}

One month old in vitro raised shoot buds and nodal segments were used for multiple shoot induction. They were cultured on MS solid medium containing different concentration $(0.3-0.9 \mathrm{mg} \Lambda)$ of TDZ and BAP. Among the various treatments, $0.6 \mathrm{mg} \Lambda$ TDZ and $0.6 \mathrm{mg} / \mathrm{BAP}$ significantly showed a higher ratio of shoot induction (5.69 and 2.60 shoots for explants) compared to control and other treatments (Table 1). Optimum percentage $(83 \%)$ of multiple shoot induction was obtained on MS medium supplemented with $0.6 \mathrm{mg} / \mathrm{TDZ}$ alone (Fig. 1A,B). High concentration of TDZ (above 0.6 $\mathrm{mg} \Lambda$ ) or BAP showed inhibited the multiple shoot induction (Table 1). Shekhawat et al. (2016) reported that the maximum number of shoot induction obtained with MS solid medium which is containing $1.0 \mathrm{mg} / \mathrm{BAP}$ and $0.2 \mathrm{mg} / \mathrm{NAA}$ in A. lanata.

Table 1. Effect of PGRs on multiple shoot induction from shoot bud and nodal explants.

\begin{tabular}{|c|c|c|c|c|c|}
\hline & PGRs & $g /)$ & Shoot bud explants & & Nodal explants \\
\hline TDZ & BAP & $\begin{array}{l}\% \text { of shoot } \\
\text { response }\end{array}$ & $\begin{array}{c}\text { No. of } \\
\text { shoots/explants }\end{array}$ & $\begin{array}{l}\text { \% of shoot } \\
\text { response }\end{array}$ & $\begin{array}{c}\text { No. of shoots / } \\
\text { explants }\end{array}$ \\
\hline 0.3 & - & 66 & $1.56 \pm 0.18^{c}$ & 70 & $1.60 \pm 0.77 \mathrm{e}$ \\
\hline 0.6 & - & 76 & $2.60 \pm 0.24^{a}$ & 83 & $5.69 \pm 0.20^{a}$ \\
\hline 0.9 & - & 68 & $1.50 \pm 0.24^{\mathrm{d}}$ & 73 & $2.22 \pm 0.18^{c}$ \\
\hline - & 0.3 & 63 & $1.26 \pm 0.20^{\mathrm{e}}$ & 67 & $1.66 \pm 0.17^{d}$ \\
\hline- & 0.6 & 70 & $1.57 \pm 0.66^{b}$ & 75 & $2.60 \pm 0.11^{b}$ \\
\hline- & 0.9 & 58 & $1.20 \pm 0.57^{f}$ & 60 & $1.50 \pm 0.17^{f}$ \\
\hline
\end{tabular}

Data represented mean \pm SE was carried out using Duncan's multiple range (DMRT) test at $p<0.05$ level. All the experiments were carried out three times with at least 20 explants. 
A comparative analysis of multiple shoot formation in solid (Agar $0.8 \%$ ) and liquid medium was also studied (Fig. 1A-F). After 5 weeks, liquid medium containing $0.6 \mathrm{mg} /$ TDZ in combination with $0.3 \mathrm{mg} A$ NAA and $0.2 \mathrm{mg} / \mathrm{IBA}$ showed a higher percentage (29.37 \pm 0.64$)$ of shoot multiplication (Fig. 1F) compared to solid medium $(12.56 \pm 1.24$; Fig. 1C). Further, subculture of these shootlets in liquid medium showed a higher ratio of response in terms of shoot length, root length, number of shoots, fresh weight and dry weight (Table 2). Gradually decrease in the number of shoots per explants $(13.37 \pm 2.67)$ was observed when liquid MS medium containing lower concentrations of $0.3 \mathrm{mg} / \mathrm{TDZ}$ in combination with $0.3 \mathrm{mg} / \mathrm{NAA}$ and $0.2 \mathrm{mg} \Lambda \mathrm{IBA}$, after 5 weeks of culture (Fig. 1E). Further, cultures on liquid MS medium containing $0.6 \mathrm{mg} / \mathrm{TDZ}$ in combination with 0.3 $\mathrm{mg} / \mathrm{NAA}$, also showed poor respondents $(7.34 \pm 1.12)$ of multiple shoot formation (Data not shown) (Fig. 1D).

Table 2. Effect of solid and liquid MS.

\begin{tabular}{lcc}
\hline \multicolumn{1}{c}{ Parameters } & \multicolumn{1}{c}{ Solid } & \multicolumn{1}{c}{ Liquid } \\
\hline Mean number of shoots per explants & $12.56 \pm 1.24$ & $29.37 \pm 0.64$ \\
Shoot length $(\mathrm{cm})$ & $4.36 \pm 0.14$ & $5.76 \pm 1.44$ \\
Root length $(\mathrm{cm})$ & $3.56 \pm 1.04$ & $4.66 \pm 0.32$ \\
Fresh weight $(\% \mathrm{w} / \mathrm{w})$ & $0.54 \pm 0.03$ & $0.86 \pm 0.63$ \\
Dry weight $(\% \mathrm{w} / \mathrm{w})$ & $0.13 \pm 0.02$ & $0.28 \pm 1.03$ \\
\hline
\end{tabular}

Medium: MS medium containing $0.6 \mathrm{mg} / \mathrm{TDZ}, 0.3 \mathrm{mg} / \mathrm{NAA}$ and $0.2 \mathrm{mg}$ /IBA. Data represented mean \pm SE was carried out using Duncan's multiple range (DMRT) test at $\mathrm{p}<0.05$ level. All the experiments were carried out three times with at least 20 explants.

The liquid culture system is the best attractive alternative compared to solid medium. The complete removal of agar, an expensive ingredient, in the multiplication medium has helped in a substantial cost reduction. It has been calculated and reported in several earlier studies (Pati et al. 2011). In the present study, in vitro raised nodal segments of $A$. lanata produced and enhanced shoot proliferation in the MS liquid medium compare than MS solid medium. Higher shoot proliferation and better response of other growth parameters such as shoot length, root length, fresh weight and dry weight in liquid medium. From this result, the liquid medium is an efficient system choice for micropropagation of $A$. lanata. The positive effect of liquid culture is the shoots are totally submerged in the medium, facilitating the uptake of nutrients and plant growth regulators in over the whole shoot surface (Hung et al. 2006). Further, this system is promoted better supply of oxygen and sucrose under the rotary culture. All shoots initiated in the liquid culture media showed uniform and vigorous shoots. Therefore, the present study concludes that regeneration of $A$. lanata in liquid culture was superior to solid culture. 

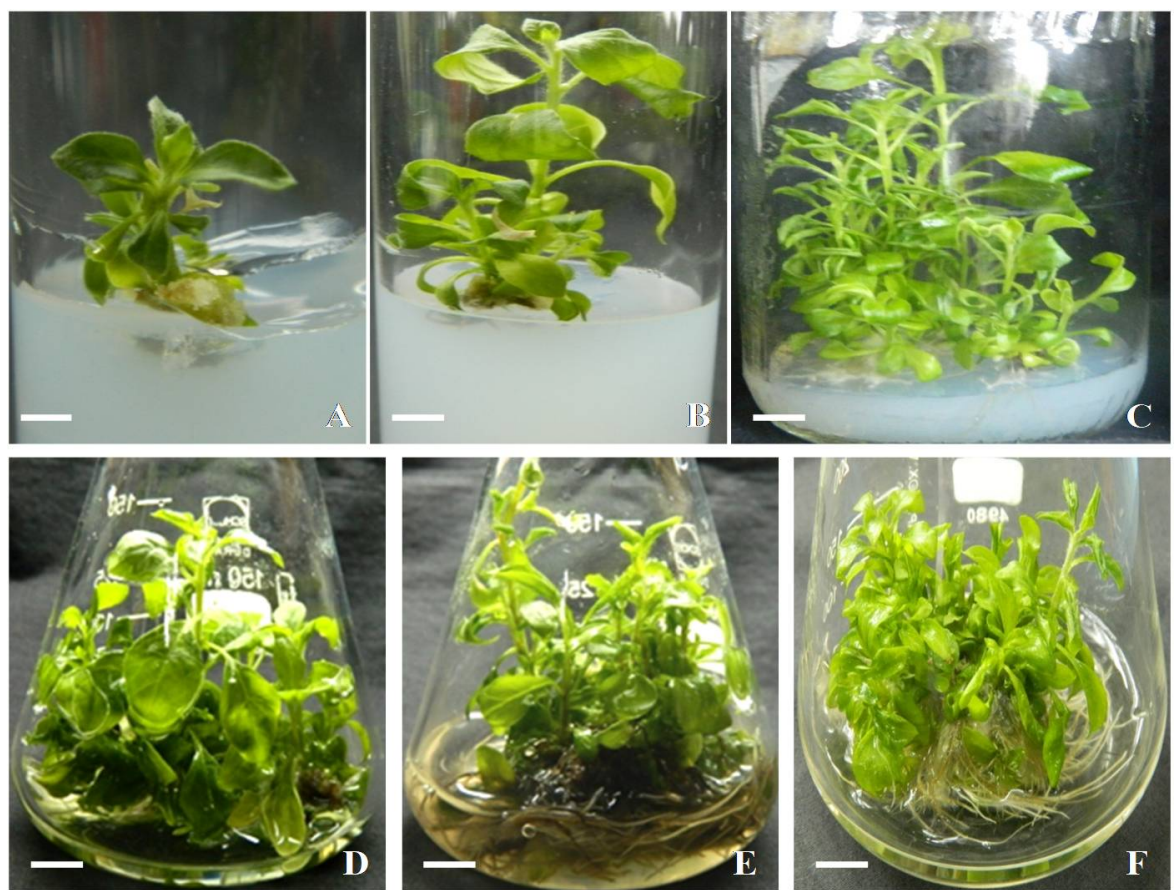

Fig. 1. Shoot multiplication in solid and liquid medium. A and B. Multiple shoot induction on MS solid medium containing $0.6 \mathrm{mg} / \mathrm{TDZ}$ after 3 weeks. C. Multiple shoot formation on MS solid medium containing 0.6 $\mathrm{mg} / \mathrm{TDZ}, 0.3 \mathrm{mg} / \mathrm{NAA}$ and $0.2 \mathrm{mg} / \mathrm{IBA}$. D. Multiple shoot formation on MS liquid medium containing $0.6 \mathrm{mg} / \mathrm{TDZ}, 0.3 \mathrm{mg} / \mathrm{NAA}$. E. Multiple shoots with spontaneous root proliferation in MS liquid medium containing $0.3 \mathrm{mg} / \mathrm{TDZ}$ in combination with $0.3 \mathrm{mg} / \mathrm{NAA}$ and $0.2 \mathrm{mg} / \mathrm{IBA}$. F. MS liquid medium containing $0.6 \mathrm{mg} / \mathrm{TDZ}, 0.3 \mathrm{mg} / \mathrm{NAA}$ and $0.2 \mathrm{mg} / \mathrm{IBA}$. Scale bars: $\mathrm{A}$ and $\mathrm{B}=0.5 \mathrm{~cm} ; \mathrm{C}$ to $\mathrm{F}=1.5 \mathrm{~cm}$.

Different volumes of liquid medium used in $150 \mathrm{ml}$ conical flask, $30 \mathrm{ml}$ medium showed the maximum number of shoot proliferation (Table 3). Further increase or decrease in the volume has led a reduction of the number of shoots. The present study also optimized the suitable culture time resulting in the number of shoots and short period of time leading to lower number of shoots. When shoots attained maximum level, no significant number of shoot multiplications had extended duration. 35 days of culture time were suitable for the maximum shoot proliferation $(29.37 \pm 0.64$ shoots/explant) in $30 \mathrm{ml}$ liquid medium. This hypothesis, in agreement with the earlier report of Scutellaria alpine (Grzegorczyk-Karolak et al. 2017).

It was also observed that, increasing liquid medium to $40 \mathrm{ml}$ promoted hyperhydricity while reducing it to $10 \mathrm{ml}$ led to desiccation of shoots within 2 weeks of subculture. Medium volume is one of the key factors for rate of shoot multiplication. In A. lanata, within 35 days of culture period and $150 \mathrm{ml}$ vessel containing $30 \mathrm{ml}$ of medium optimum for higher number of shoot multiplication. The 50 days of culture period were induced chlorosis. Chu et al. (1993) reported that the growth of miniature rose shoots cultured on $30 \mathrm{ml}$ liquid medium had a higher multiplication ratio than those grown in 
10 or $20 \mathrm{ml}$. Increasing the volume caused a least number of shoots; it could be due to hyperhydricity as a result of the lower availability of oxygen (Sandal et al. 2001, Pati et al. 2011).

Table 3. Effect of medium volume on multiple shoot formation.

\begin{tabular}{lcccc}
\hline \multirow{2}{*}{$\begin{array}{l}\text { Volume of } \\
\text { medium }(\mathrm{ml})\end{array}$} & \multicolumn{4}{c}{ Mean number of shoots per explants during different days of subculture } \\
\cline { 2 - 5 } & 14 days & 21 days & 28 days & 35 days \\
\hline 10 & $2.34 \pm 0.50^{\mathrm{c}}$ & $0.00^{\mathrm{e}}$ & $0.00^{\mathrm{e}}$ & $0.00^{\mathrm{e}}$ \\
20 & $3.25 \pm 0.60^{\mathrm{b}}$ & $5.87 \pm 0.73^{\mathrm{b}}$ & $9.24 \pm 0.56^{\mathrm{b}}$ & $14.23 \pm 0.59^{\mathrm{b}}$ \\
$\mathbf{3 0}$ & $\mathbf{4 . 5 4 \pm \mathbf { 0 . 2 4 }}$ & $\mathbf{7 . 4 6} \pm \mathbf{0 . 5 6 ^ { \mathrm { a } }}$ & $\mathbf{1 6 . 5 5 \pm 0 . 3 4 ^ { \mathrm { a } }}$ & $\mathbf{2 9 . 3 7 \pm 0 . 6 4 ^ { \mathrm { a } }}$ \\
40 & $2.14 \pm 0.14^{\mathrm{d}}$ & $3.39 \pm 0.36^{\mathrm{c}}$ & $5.66 \pm 0.54^{\mathrm{c}}$ & $9.59 \pm 0.40^{\mathrm{c}}$ \\
50 & $1.38 \pm 0.12^{\mathrm{e}}$ & $2.14 \pm 0.15^{\mathrm{d}}$ & $3.24 \pm 0.36^{\mathrm{d}}$ & $5.34 \pm 0.20^{\mathrm{d}}$ \\
\hline
\end{tabular}

Medium-MS liquid medium containing $0.6 \mathrm{mg} / \mathrm{TDZ}, 0.3 \mathrm{mg} / \mathrm{NAA}$ and $0.2 \mathrm{mg} / \mathrm{IBA}$

Data represented mean $\pm \mathrm{SE}$ was carried out using Duncan's multiple range (DMRT) test at $P<0.05$ level. All the experiments were carried out three times with at least 20 explants.

This study presents for the first time a complete protocol for in vitro mass propagation of A. lanata in a liquid culture system using cytokinnin and auxin. The protocol could also be helpful for the improvement of medicinal content by genetic engineering of this medicinally and pharmaceutically important plant of $A$. lanata.

\section{Acknowledgments}

The authors thank to DST, Government of India, for providing facilities through FIST program. They are also thank to the University Grants Commission, New Delhi, for its support through "College with Potential for Excellence" programme.

\section{References}

Aitken-Christie J, Kozai T and Takayama S (1995) Automation in plant tissue culture. General introduction and overview. In: Aitken-Christie J, Kozai T, Smith MAL (eds) Automation and environmental control in plant tissue culture. Kluwer, The Netherlands, pp. 1-18.

Arigundam U, Variyath AM, Siow YL, Marshall D and Debnath SC (2020) Liquid culture for efficient in vitro propagation of adventitious shoots in wild Vacinium vitis-idaea ssp. Minus (lingonberry) using temporary immersion and stationary bioreactors. Scientia Horticulturae 264: 1-9.

Chu CY, Knight SL and Smith MAL (1993) Effects of liquid culture on the growth and development of miniature rose (Rosa chinensis Jacq. 'Minima'). Plant Cell Tiss. Org. Cult. 32: 329-334.

Deterz C, Ndiaye S and Dreyfus B (1994) In vitro regeneration of tropical multipurpose leguminous tree Sesbania grandiflora from cotyledon explants. Pla. Cell Rep. 14: 87-93. 
Girach RD, Aminuddin SPA and Khan SA (1994) Traditional plant remedies among the Kondh of district Dhenkal (Orissa). Int. J. Pharmacogn. 32: 274-283.

Grzegorczyk-Karolak I, Rytczak P, Bielecki S and Wysokińska (2017) The influence of liquid systems for shoot multiplication, secondary metabolite production and plant regeneration of Scutellaria alpine. Plant Cell Tiss. Org. Cult. 128: 479-486.

Gupta AK and Neeraj T (2004) Reviews on Indian medicinal plants. Vol. I, ICMR, New Delhi, pp. 338-340.

Hung CD, Johnson K and Torpy F (2006) Liquid culture for efficient micropropagation of Wasabia japonica (Miq.) Matsumura. In vitro cell Dev. Biol. Plant. 42: 548-552.

John D (1984) One hundred useful raw drugs of the Kani tribes of Trivandrum forest division, Kerala, India. Int. J. Crude Drug Res. 22: 17-19.

Joseph S and Mathew B (2015) Microwave assisted facile green synthesis of silver and gold nanocatalysts using the leaf extract of Aerva lanata. Spectrochimica Acta Part A: Molecular and Biomolecular Spectro.: 1371-1379.

Mukerjee T, Bhalla N, Singh AG and Jain HC (1984) Herbal drugs for urinary stones. Ind. Drugs 21:224-228.

Pati PK, Kaur J and Singh P (2011) A liquid culture system for shoot proliferation and analysis of pharmaceutically active constituents of Catharanthus roseus (L.) G. Don. Plant Cell Tiss. Org. Cult. 105: 299-307.

Rajesh R, Chitra K and Paarakh PM (2011) Aerva lanata (L.) Juss. ex Schult. - An overview". Ind. J. Natu. Prod. Reso. 2(1): 5-9.

Sandal I, Bhattacharya A and Ahuja PS (2001) An efficient liquid culture system for tea proliferation. Plant Cell Tiss. Org. Cult. 65: 75-80.

Selvam R, kalaiselvi P, Govindaraj A, Bala Murugam V and Sathish Kumar AS (2001) Effect of Aerva lanata leaf extract and vedippu chunnam on the urinary risk factors of calcium oxalate urolithiasis during experimental hyperoxaluria. Pharmaco. Res. 43(1): 89-93.

Shekhawat MS, Manokari M and Revathi J (2016) In vitro propagation and ex vitro rooting of Aerva lanata (L.) Juss. ex Schult.: A rare medicinal plant. Ind. J. Pla. Physiol. 22: 40-47.

Sikarwa RLS and Kaushik JP (1993) Folk medicines of the Morena district, Madhya Pradesh, India. Int. J. Pharmaco. 31: 283-287.

Sivanandhan G, Rajesh M, Arun M, Jeyaraj M, Kapil Dev G, Arjunan A, Manickavasagam M, Muthuselvam M, Selvaraj N and Ganapathi A (2013) Effect of culture conditions, cytokinins, methyl jasmonate and salicylic acid on the biomass accumulation and production of withanolides in multiple shoot culture of Withania somnifera (L.) Dunal using liquid culture. Acta Physiol. Pla. 35: 715-728.

Smith MAL and Spomer LA (1995) Vessels, gels, liquid media and support systems. In: AitkenChristie J, Kozai T, Smith MAL (eds) Automation and environmental control in plant tissue culture. Kluwer, The Netherlands, pp. 371-404.

Soundar Raju C, Varutharaju K, Thilip C, Aslam A and Shajahan A (2015) Rhizogenesis in Cell Suspension Culture from Mango Ginger: A Source of Isosorbide and n-Hexadecanoic Acid. Advances in Bot, Volume 2015, Article ID 942761, 7 pages.

Surya MS, Ashiq M and Jayachandran K (2012) In vitro production of vanillin from suspension culture of Aerva lanata (L.) Juss. ex Schult. Ind. J. Life Sci. 2(1): 9-15. 
Thilip C, Soundar Raju C, Varutharaju K, Aslam A and Shajahan A (2015) Establishment of adventitious root culture from cell suspensions of Withania somnifera (L.) Dunal: An in vitro approach for production of withanolides. Int. J. Pharm. Bio. Sci. 6(1): 1030-1037.

Varutharaju K, Soundar Raju C, Thilip C, Aslam A and Shajahan A (2014) High Efficiency Direct Shoot Organogenesis from Leaf Segments of Aerva lanata (L.) Juss. Ex Schult by using Thidiazuron. The Sci World J.doi.org/10.1155/2014/652919.

(Manuscript received on 25/01/2020; revised on 06/04/2021) 